\title{
Prevalence of low back pain and associated factors among physiotherapy students
}

\author{
Prevalência e fatores associados a dor lombar em estudantes de fisioterapia
}

Markeyllanne Leocadio Morais ${ }^{1}$, Vanessa Kely Oliveira Silva ${ }^{1}$, José Mário Nunes da Silva²

DOI 10.5935/2595-0118.20180047

\section{ABSTRACT}

BACKGROUND AND OBJECTIVES: Precise estimates about the prevalence of low back pain in college students, especially in physiotherapy students, are necessary to evaluate their development landscape, producing global health indicators for the investigated group and preventing habits that can accelerate the generation of the pain incapacitation process. Therefore, this study aimed to analyze the factors associated with low back pain in physiotherapy students.

METHODS: A total of 410 undergraduate students were surveyed, answering questionnaires relating to socio-demographic data, health aspects, lifestyle and the Nordic Questionnaire for Musculoskeletal Symptoms to determine the presence of low back pain.

RESULTS: The prevalence of low back pain reported in the last year was $56.3 \%$ (95\% CI: 51.5-61.2) and was associated with social class $A$ and $B$, having an occupation, visited the doctor in the last 12 months, self-report of low back pain and to the year in course.

CONCLUSION: There was a high prevalence of low back pain in university students, so it is suggested that some measures are incorporated to understand the magnitude of the effects caused by this pain, and consequently find the best preventive and intervention strategies.

Keywords: Low back pain, Musculoskeletal pain, Prevalence, Risk factors, Students.

1. Faculdade de Ciências e Tecnologia do Maranhão, Departamento de Fisioterapia, Caxias, MA, Brasil.

2. Universidade Federal do Piauí, Departamento de Medicina Comunitária, Teresina, PI, Brasil.

Submitted in January 23, 2018.

Accepted for publication on June 27, 2018.

Conflict of interests: none - Sponsoring sources: none.

Correspondece to:

José Mário Nunes da Silva

Departamento de Medicina Comunitária

Av. Frei Serafim 2280 - Centro

64001-020 Teresina, PI, Brasil.

E-mail: zemariu@hotmail.com

(c) Sociedade Brasileira para o Estudo da Dor

\section{RESUMO}

JUSTIFICATIVA E OBJETIVOS: Estimativas precisas de prevalência de dor lombar em universitários, especialmente em estudantes de fisioterapia, são necessárias para avaliar o seu panorama de desenvolvimento, produzindo indicadores globais de saúde para o grupo investigado e prevenindo hábitos que possam acelerar a geração do processo de incapacitação pela dor. Portanto, este estudo teve como objetivo analisar os fatores associados à dor lombar em estudantes de fisioterapia.

MÉTODOS: Foram pesquisados 410 universitários, sendo aplicados questionários referentes a dados sociodemográficos, aspectos de saúde, estilo de vida e o Questionário Nórdico para Sintomas Osteomuscular para determinar a presença de dor lombar.

RESULTADOS: A prevalência de dor lombar relatada no último ano foi de 56,3\% (IC95\%: 51,5-61,2) e associou-se estatisticamente com classe social A e B, possuir ocupação, visitar o médico nos últimos 12 meses, autorrelato de dor lombar e ao ano do curso. CONCLUSÁO: Houve alta prevalência de dor lombar nos universitários. Assim, sugere-se que sejam tomadas algumas medidas com intuito de compreender a dimensão dos efeitos que essa dor provoca, e consequentemente encontrar meios para melhores estratégias preventivas e de intervenção.

Descritores: Dor lombar, Dor musculoesquelética, Estudantes, Fatores de risco, Prevalência.

\section{INTRODUCTION}

Low back pain (LBP) is characterized as a referred pain below the margin of the last ribs and above the inferior gluteal lines, with or without pain in the lower limbs ${ }^{1,2}$ and only $10 \%$ of back pain are related to a specific cause of a particular disease ${ }^{3}$.

LBP is one of the most widespread public health problems faced by the industrialized world. It is a heavy burden for the national health systems and social security regarding diagnosis, treatment, absenteeism and premature retirement ${ }^{4,5}$. Further, the psychosocial impact caused by the premature cocooning of active people under other aspects, from their everyday activities ${ }^{6}$.

Meucci, Fassa and Faria ${ }^{7}$, and Nascimento and Costa ${ }^{8}$ demonstrated that the prevalence of back pain in young adults ranges from 13.0 to $30 \%$, and it is estimated that this condition can reach up to $65 \%$ of the general population, annually, and up to $84 \%$ of the people in some moment of their life. Furtado et al. ${ }^{5}$ reported a prevalence of $29.3 \%$ LBP in college students aged from 18 to 29 years. 
Despite these numbers, a specific diagnosis on the possible causes of the LBP is not determined in 90 and $95 \%$ of the cases since the LBP has a multifactorial character. However, some authors relate the presence of LBP to a set of causes, such as sociodemographic factors, health status, lifestyle and occupational factors ${ }^{5,9-11}$.

Considering the presence of LBP as a cause that limits the physical, emotional and cognitive skills of an individual, especially college students ${ }^{12}$, it is necessary to study the precise estimates of prevalence university students, especially in students of physical therapy, to assess the development situation of the LBP, to produce global health indicators for the investigated group, and to prevent habits that can speed up the disabling process of pain. The objective of this study was to analyze the factors associated with the LBP in university students.

\section{METHODS}

This is an exploratory, descriptive, cross-sectional field research. The sampling was of the simple random probabilistic type, considering a total of 445 students enrolled in the surveyed period. The calculation of the sample was estimated assuming a prevalence of $45.2 \%{ }^{13}$, maximum error of $5 \%$ to a significance interval of $95 \%$ and using a correction factor of 1.5 for the outcome of the design. The sample was increased in 30\% assuming the non-response rate and to control confusion factors, resulting in a total of 400 college students.

The inclusion criteria of this research were to be a physiotherapy student, of both genders, aged between 18 and 44 years who agreed to participate in the study and signed the Free and Informed Consent Form (FICT).

The exclusion criteria were pregnant women, students with musculoskeletal pain or lesions due to recent infectious, onco-hematological, genetic and traumatic diseases, and those who did not agree to participate in the study. Data collection was from May to June 2017.

The Nordic Musculoskeletal Questionnaire (NMQ) ${ }^{14}$, validated and adapted to the Portuguese language ${ }^{15}$ was used to assess the LBP and the outcome. For the study, LBP was defined as pain or discomfort in the last 12 months, not related to trauma or menstrual pain, with a minimum duration of one day, associated or not with irradiation to one or both lower limbs ${ }^{6,11}$.

Other independent variables were also investigated in the following.

- Sociodemographic and economic variables: gender, age, marital status, race/color, religion, family income, social class (ABEP - Brazilian Association of Research Companies - 2016 - www. abep.org), place of residence, number of people living in the domicile, with/without children, occupation, school, course and year of the course;

- Lifestyle: the practice of physical activity, alcohol consumption, illicit drug use, nutritional status;

- Self-reported health aspects: healthcare plan, visit the doctor in the last 12 months, morbidities, sleep satisfaction, health and stress self-perception.

The research project was approved by the Research Ethics Committee of the School of Science and Technology of Maranhão (FACEMA) with register number at CAAE 61597016.0.0000.8007 and opinion number 1.947.138. The study followed the resolution No. 466/12 of the National Health Council and Declaration of Helsinki of the World Medical Association.

\section{Statistical analysis}

The data were organized and tabulated using the SPSS version 18.0 for Windows (SPSS Inc., Chicago, IL 60606, USA).

The descriptive statistical procedures were applied in the univariate analysis. Pearson`s $\chi^{2}$ Chi-square test was applied in the bivariate analysis.

The Poisson regression was used for the multivariate analysis with a robust variance of standard errors ${ }^{16}$ with all covariates of interest that presented $\mathrm{p}<0.20$ in the bivariate analysis.

Three multivariate models were created, adopting a hierarchic entry $^{17}$ of variables, in which the significant correlations (LBP and independent variables) were adjusted by confusion factors. The first entry, sociodemographic, economic and occupational variables (gender, social class, and occupation). The second entry, model adjusted by sociodemographic, economic, occupational and lifestyle variables (physical activity). The third entry, model adjusted by sociodemographic, economic, occupational, lifestyle and year of the course variables.

The gross and adjusted prevalence ratios were calculated with their respective confidence intervals of 95\% (CI95\%), and significance obtained by the Wald test.

A significance level of $5 \%$ was used in all the analyses.

\section{RESULTS}

The final number of students surveyed was 410 . The prevalence of LBP in the last year was 56.3\% (CI95\%:51.5-61.2); and in the last week, 27.1\% (CI95\%:22.8-31.4). The LBP that led to an appointment with a professional was 8.0\% (CI95\%:5.410.7), while $14.9 \%$ (CI95\%:11.4-18.3) of the respondents were not able to perform their normal activities in the last year because of the pain.

Of the total number of interviewees, $72.9 \%$ were female, $43.2 \%$ were in the $21-24$ years age group, with an average age of $22.8 \pm 5.0$ years, $81.2 \%$ were single/divorced, and $51.2 \%$ were attending the $3^{\text {rd }}$ and $4^{\text {th }}$ school year (Table 1 ).

Table 2 shows the data related to lifestyle and health aspects.

Regarding LBP, the following variables were associated with their occurrence in the bivariate analysis: social class $(\mathrm{p}=0.017)$, course year $(\mathrm{p}=0.011)$, practice of physical activity $(\mathrm{p}=0.022)$ visited the doctor in the last 12 months $(\mathrm{p}<0.001)$ and self-reported LBP $(\mathrm{p}<0.001)$ (Tables 1 and 2).

In the multivariate analysis, through the Poisson regression ( $\mathrm{Ta}-$ ble 3), it was observed an increase in the prevalence of LBP in students of classes $A$ and $B\left(\mathrm{PR}_{2}=1.25\right)$, who went to the doctor in the past 12 months $\left(\mathrm{PR}_{\mathrm{aj}}=1.40\right)$, self-reported LBP as infrequent $\left(\mathrm{PR}_{\mathrm{aj}}=2.29\right)$, frequently $\left(\mathrm{PR}_{\mathrm{aj}}=2.80\right)$ and always $\left(\mathrm{PR}_{\mathrm{aj}}=3.13\right)$, and on those who were in the third year $\left(\mathrm{PR}_{\mathrm{aj}}=1.52\right)$, fourth year $\left(\mathrm{PR}_{\mathrm{aj}}=1.52\right)$ and fifth year $\left(\mathrm{PR}_{\mathrm{aj}}=1.66\right)$ of the course. 
Table 1. Prevalence of low back pain in the last 12 months according to the socioeconomic and demographic characteristics of the students participating in the study. Caxias-MA, 2017

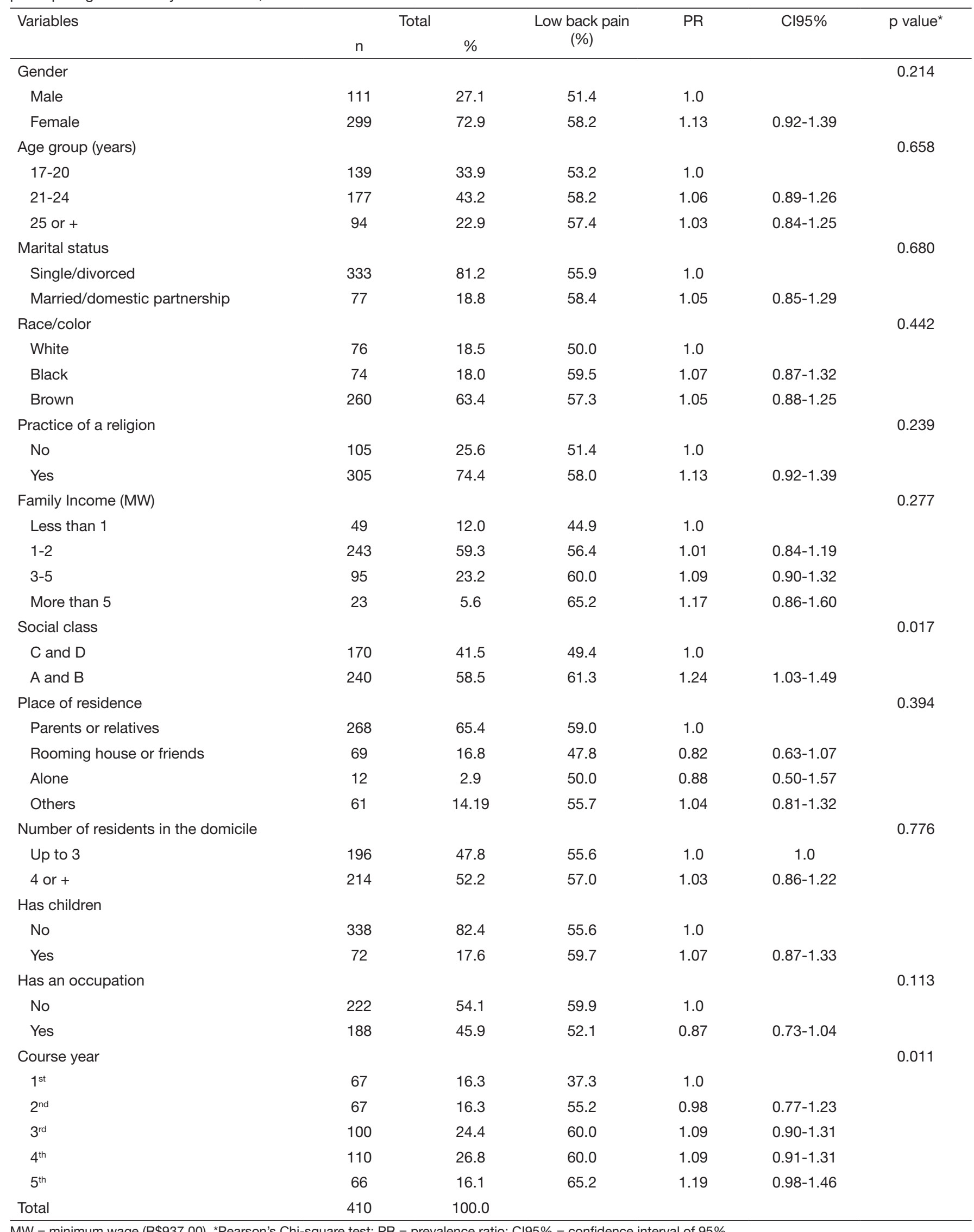

$\mathrm{MW}=$ minimum wage $(\mathrm{R} \$ 937,00),{ }^{*}$ Pearson's Chi-square test; $\mathrm{PR}=$ prevalence ratio; Cl95\% = confidence interval of $95 \%$. 
Table 2. Lifestyle, use of healthcare services and health conditions of college students participating in the research. Caxias-MA, 2017

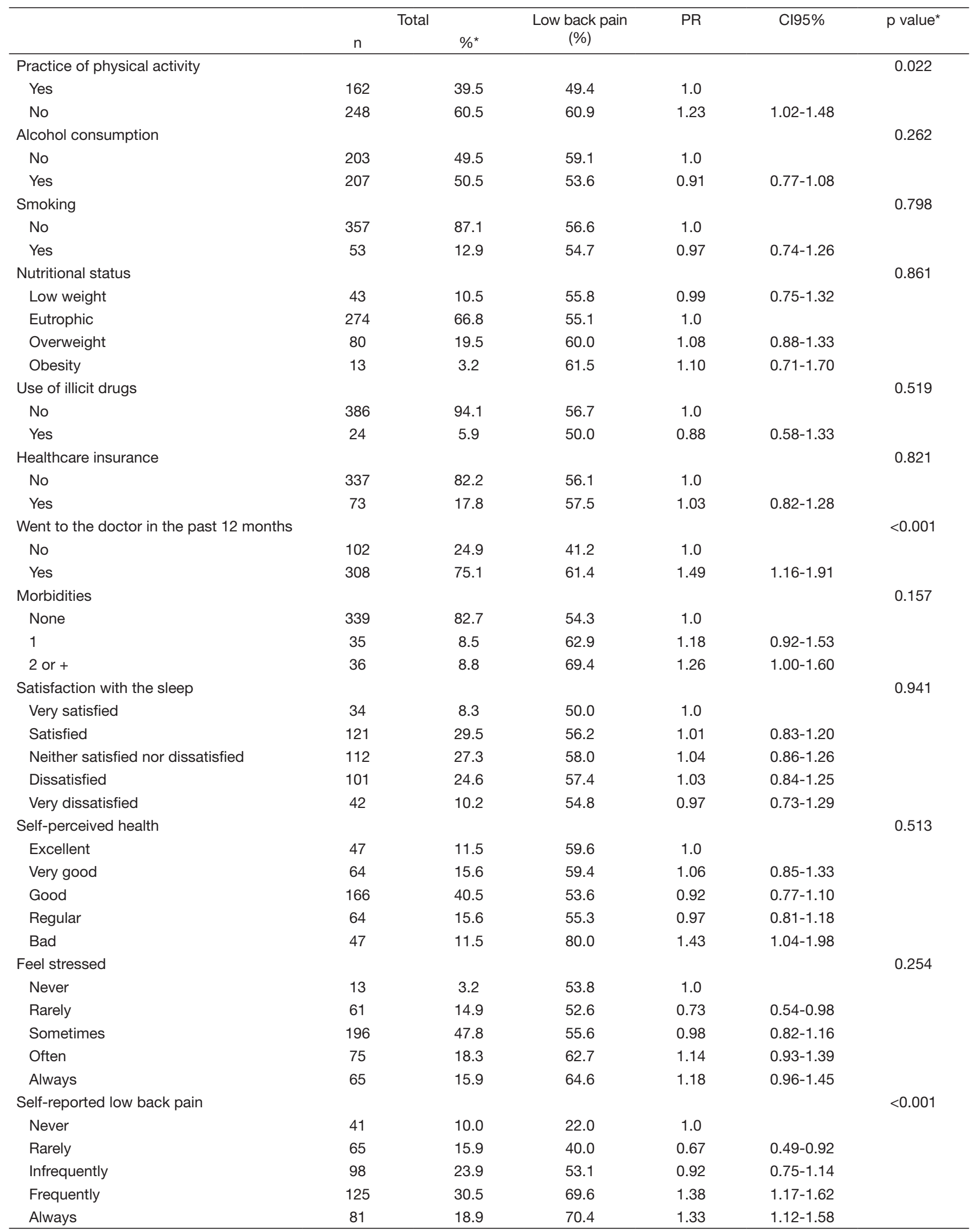

*Pearson's Chi-square test; PR = prevalence ratio; Cl95\% = confidence interval of $95 \%$. 
Table 3. Multivariate analysis using Poisson regression for the independent factors associated with low back pain in the past 12 months

\begin{tabular}{|c|c|c|c|}
\hline Variables & $\begin{array}{c}\text { Model } 1 \\
\text { PR (Cl95\%) }\end{array}$ & $\begin{array}{c}\text { Model } 2 \\
\text { PR (Cl95\%) }\end{array}$ & $\begin{array}{c}\text { Model } 3 \\
\text { PR (Cl95\%) }\end{array}$ \\
\hline \multicolumn{4}{|l|}{ Gender } \\
\hline Female & $1.13(0.92-1.38)$ & $0.97(0.80-1.17)$ & $0.95(0.79-1.15)$ \\
\hline \multicolumn{4}{|l|}{ Social class } \\
\hline \multicolumn{4}{|c|}{ Has an occupation } \\
\hline No & 1,0 & 1,0 & 1,0 \\
\hline Yes & $0.86(0.72-1.02)$ & $0.83(0.70-0.98)$ & $0.80(0.67-0.95)$ \\
\hline \multicolumn{4}{|c|}{ Practice physical activity } \\
\hline Yes & & $1.42(1.13-1.80)$ & $1.40(1.11-1.76)$ \\
\hline \multicolumn{4}{|l|}{ Morbidities } \\
\hline None & & 1,0 & 1,0 \\
\hline 1 & & $1.06(0.82-1.39)$ & $1.01(0.78-1.31)$ \\
\hline 2 or + & & $1.13(0.91-1.41)$ & $1.09(0.87-1.37)$ \\
\hline \multicolumn{4}{|c|}{ Self-reported low back pain } \\
\hline Never & & 1,0 & 1,0 \\
\hline Rarely & & $1.77(0.94-3.32)$ & $1.71(0.92-3.21)$ \\
\hline Infrequently & & $2.33(1.28-4.22)$ & $2.29(1.27-4.12)$ \\
\hline $4^{\text {th }}$ & & & $1.52(1.11-2.09)$ \\
\hline $5^{\text {th }}$ & & & $1.66(1.20-2.28)$ \\
\hline
\end{tabular}

$\mathrm{PR}=$ prevalence ratio; Cl95\% = confidence interval of 95\%; Model-1 = model adjusted by socioeconomic variables (gender, social class and occupation); Model-2 = model adjusted by socioeconomic variables, lifestyle and health; Model-3 = model adjusted by socioeconomic variables, lifestyle, health and course year. Note: Data in bold represent a prevalence ratio and a confidence interval statistically significant by the Wald test.

In the study, the fact that the student had an occupation presented as a protective factor, decreasing by $20 \%$ the prevalence of LBP.

\section{DISCUSSION}

Since LBP is be defined as a symptom, and not a disease, investigative studies heavily rely on the subject's information and memory. The frequency of the outcomes may present different results depending on the accepted definitions since the data collection varied in different studies ${ }^{11,18-21}$.

The recent interest in studying the prevalence of LBP in the Brazilian population may be due to the financial cost generated by this condition, in the last years, to the healthcare system and social security ${ }^{20,22}$.

In this study, the prevalence of LBP in the last year was 56.3\%, showing similarity when compared to other research. In a study conducted by Matos et al. ${ }^{20}$ the prevalence of reported back pain by the population last year was $71.5 \%$, and the most affected region was the lumbar spine, accounting for a prevalence of $52.8 \%$ in the year. In another study conducted by Bejia et al. ${ }^{23}$ with workers showed a variation in the annual prevalence equivalent to this latter study (52.1\%).

In Andrusaitis, Oliveira and Barros Filho ${ }^{24}$ study with truck drivers from the state of São Paulo, the observed prevalence was 59\%. A study conducted by Falavigna et al. ${ }^{25}$ with students of physical therapy and medicine course of the University of Caxias do Sul 
(Rio Grande do Sul) reached a prevalence of $66.8 \%$ annually, showing a slight change compared to those already described. Cavalcante Filho et al. ${ }^{26}$ conducted a study with adolescents (ages from 11 to 18 years) of a private school in a city in the State of Piauí where it was observed a high prevalence of LBP (78\%). In a study populational study conducted by Noll et al. ${ }^{27}$ with children and teenagers from 11 to 16 years, it was found a prevalence of back pain in the past three months of $55.7 \%$. Silva et al. ${ }^{28}$ studied 395 students from all years of the course of medicine of the University of Taubaté and observed a $35.69 \%$ prevalence of chronic pain that they defined as persistent lasting for more than 6 months.

In a systematic review carried by Nascimento and $\operatorname{Costa}^{8}$ in Brazil, it was evidenced, in the different analyzed studies, an LBP prevalence higher than $50 \%$, disagreeing with the Almeida et al. ${ }^{29}$ study developed with adults over 20 years of age, residents in the city of Salvador (Bahia), that showed a prevalence of $14.7 \%$. In a study conducted by Fernandes et al. ${ }^{30}$ with workers of the plastic industry in the city of Salvador (Bahia), the annual prevalence of LBP was $28.9 \%$.

In the bivariate analysis, among the statistically significant elements related to LBP, it was evidenced that the significant variables were the social class, year of the course, the practice of physical activity, visited the doctor in the past 12 months and self-reported LBP. However, the variable practice of physical activity lost its significance in the multivariate analysis.

Also, regarding the risk factors, no statistically significant association was found with the gender variable. However, in a study conducted by Ferreira et al. ${ }^{31}$ they concluded that the females had a greater prevalence since women are increasingly combining household activities with their work outside, becoming more prone to ergonomic loads, mainly repeatability, vicious posture and work at great speed.

Another factor favoring this prevalence is the fact that females have some functional anatomy characteristics (lower stature, lower muscle mass, lower bone mass, more fragile joints and less adapted to physical exertion, greater fat weight) and linked to the modulation of the nervous system, which may contribute to the onset and greater intensity of pain ${ }^{32-35}$.

A study conducted in Brazil by Malta et al. ${ }^{18}$ found a prevalence of chronic back pain of $15.5 \%$ (CI95\% 14.7-16.4) in men and $21.1 \%$ (CI95\% 20.2-22.0) in women.

In relation to social class, one can notice that the prevalence of LBP increased $25 \%$ in classes A and B when compared to classes $\mathrm{C}$ and $\mathrm{D}$, contrary to Almeida et al. ${ }^{29}$ that identified the social class as a protective factor for low back pain.

The variable occupation was considered a protective factor for LBP, reducing the prevalence by $20 \%$. This result can be justified by the fact that during the execution of their tasks, individuals can be moving, even with a little effort, such as walking from home to work. Consequently, this will force them not to stay at home developing sedentary habits.

Contrary to the study by Andrusaitis, Oliveira and Barros Fil$\mathrm{ho}^{24}$ in which they report that occupations, where the worker remains seated for a long period of time, would be a factor with a positive association with lower back pain. In their study,
Silva, Fassa and Valle ${ }^{35}$ also showed that occupations in which individuals spend a lot of time lifting weight or performing repetitive movements increase the probability of developing LBP. In the present study, there was no association between the practice of physical activity and LBP. However, Oliveira, Salgueiro and Alfier ${ }^{36}$ state that this type of activity would be a preventive factor since it would strengthen the muscles in general, which contradicts the research conducted by Dijken et al. ${ }^{37}$ that showed that the association of low back pain with practitioners of physical activity is more common in individuals who have physically demanding jobs.

To Malta et al. ${ }^{18}$ the variable practice of physical activity at work, intense or heavy, and also, the heavy physical activity at home, were associated with the prevalence of chronic back pain. Ferreira et al. ${ }^{31}$ even say that heavy physical activity is not considered beneficial to the health, because it causes fatigue, muscle and joint overload, leading to a series of musculoskeletal problems.

Having visited the doctor in last the 12 months increased by $40 \%$ the prevalence of LBP. This can be explained by the fact that the individuals who sought medical advice were those who have had some musculoskeletal dysfunction. This may have been the cause for the demand, while those who do not visit a doctor for years may have infrequent reporting.

In this study, the self-reported LBP increased the prevalence of LBP. Fonseca and Serranheira ${ }^{38}$ stated that the prevalence of musculoskeletal symptoms in different anatomical areas over a period of 12 months is high (84\%), reaching mostly the lumbar region (65\%). Serranheira, Pereira and Santos ${ }^{39}$ stated that the self-reported prevalence value for the lumbar region was $55.4 \%$.

The present study showed that moving forward in the course had a direct relationship with the increase in the prevalence of LBP. Since this is a study with college students of the health area, the result may be a consequence of the task overload, which may prevent students from performing physical activities and lead to the adoption of inadequate postures ${ }^{27,28}$.

Corroborating the study by Dominguez et al. ${ }^{40}$ carried with students and employees of a university center that elaborates the idea that psychological factors such as stress, dissatisfaction, anguish, demotivation and psychological overloads in populations that are in a relentless search for professional improvement in a competitive society, can generate painful processes in the lumbar region ${ }^{41}$.

During the academic phase, LBP can directly affect the quality of life of college students, and consequently cause a poorer academic performance, since the year of the course contributes to the onset of problems that affect the lumbar spine ${ }^{26-28}$.

LBP is a cause that affects thousands of individuals. However, the findings considered risk factors for this population point to the need for the implementation of new services that promote health, aiming at complementary measures to minimize this painful picture.

As the present study was conducted only with college students, the result cannot be extrapolated; and due to its cross-sectional character, one cannot infer causality. 


\section{CONCLUSION}

There was a high prevalence of LBP in the college students surveyed, showing a significant association with the social class, occupation, having visited the doctor in the last 12 months, self-reported LBP and year of the course.

Therefore, it is still necessary to have more information about the prevalence of LBP in order to understand the magnitude of the effects caused by this pain, and consequently find ways to develop a better preventive and intervention strategy.

\section{REFERENCES}

1. Lizier DT, Perez MV, Sakata RK. Exercices for treatment of nonspecific low back pain. Rev Bras Anestesiol. 2012;62(6):838-46.

2. Van Middelkoop M, Rubinstein SM, Verhagen AP, Ostelo RW, Koes BW, van Tulder MW. Exercise therapy for chronic nonspecific low-back pain. Best Pract Res Clin Rheumatol. 2010;24(2):193-204

3. Stanton TR, Latimer J, Maher CG, Hancock MJ. How do we define the condition 'recurrent low back pain'? A systematic review. Eur Spine J. 2010;19(4):533-9.

4. Luo X, Pietrobon R, Sun SX, Liu GG, Hey L. Estimates and patterns of direct health care expenditures among individuals with back pain in the United States. Spine. 2004;29(1):79-86.

5. Furtado RN, Ribeiro LH, Abdo Bde A, Descio FJ, Martucci CE Jr, Serruya DC. [Nonspecific low back pain in young adults: associated risk factors]. Rev Bras Reumatol. 2014;54(5):371-7. Portuguese.

6. Hoy D, Bain C, Williams G, March L, Brooks P, Blyth F, et al. A systematic review of the global prevalence of low back pain. Arthritis Rheum. 2012;64(6):2028-37.

7. Meucci RD, Fassa AG, Faria NM. Prevalence of chronic low back pain: systematic review. Rev Saude Publica. 2015;49:73.

8. Nascimento PR, Costa LO. [Low back pain prevalence in Brazil: a systematic review. Cad Saude Publica. 2015;31(6):1141-56. English, Portuguese.

9. Krismer M, van Tulder M. Strategies from prevention and management of musculoskeletal conditions. Low back pain (non-specific). Best Pract Res Clin Rheumatol. 2007;21(1):77-91.

10. O'Sullivan P. Diagnosis and classification of chronic low back pain disorders: maladaptive movement and motor control impairments as underlying mechanism. Man Ther. 2005;10(4):242-55.

11. De Vitta A, Martinez MG, Piza NT, Simeão SF, Ferreira NP. [Prevalence of lower back pain and associated factors in students]. Cad Saude Publica. 2011;27(8):1520-8. Portuguese.

12. Bacchi CD, Candotti CT, Noll M, Minossi CE. Avaliaçăo da qualidade de vida, da dor nas costas, da funcionalidade e de alteraçóes da coluna vertebral de estudantes de fisioterapia. Motriz Rev Educ Fís. 2013;19(2):243-51.

13. Saes MO, Soares MC. Fatores associados à dor na coluna vertebral em adolescentes de escolas públicas de um município do extremo sul do Brasil. Rev Salud Pública. 2017;19(1):105-11.

14. Kuorinka I, Jonsson B, Kilbom A, Vinterberg H, Biering-Sorensen F, Andersson G, et al. Standardised Nordic questionnaires for the analysis of musculoskeletal symptoms. Appl Ergon. 1987;18(3):233-7.

15. Pinheiro FA, Troccoli BT, Carvalho CV. [Validity of the Nordic Musculoskeletal Questionnaire as morbidity measurement tool]. Rev Saude Publica. 2002;36(3):30712. Portuguese.

16. Camey SA, Torman VB, Hirakata VN, Cortes RX, Vigo A. Bias of using odds ratio estimates in multinomial logistic regressions to estimate relative risk or prevalence ratio and alternatives. Cad Saude Publica. 2014;30(1):21-9.

17. Chiavegatto Filho AD, Wang YP, Malik AM, Takaoka J, Viana MC, Andrade LH.
Determinants of the use of health care services: multilevel analysis in the Metropolitan Region of Sao Paulo. Rev Saude Publica. 2015;49:15.

18. Malta DC, Oliveira MM, Andrade SS, Caiaffa WT, Souza MF, Bernal RT. Factors associated with chronic back pain in adults in Brazil. Rev Saude Publica. 2017;51 (Suppl 1):9s. English, Portuguese.

19. Almeida DC, Kraychete DC. Low back pain - a diagnostic approach. Rev. Dor 2017;18(2):173-7.

20. Matos MG, Hennington EA, Hoefel AL, Dias-da-Costa JS. [Lower back pain in health insurance policyholders: prevalence and associated factors]. Cad Saude Publica. 2008;24(9):2115-22. Portuguese.

21. Zanuto EA, Codogno JS, Christófaro DG, Vanderlei LC, Cardoso JR, Fernandes RA. Prevalence of low back pain and associated factors in adults from a middle-size Brazilian city]. Cien Saude Colet. 2015;20(5):1575-82. English, Portuguese.

22. Meziat Filho N, Silva GA. Disability pension from back pain among social security beneficiaries, Brazil. Rev Saude Publica. 2011;45(3):494-502. English, Portuguese.

23. Bejia I, Younes M, Jamila HB, Khalfallah T, Salem KB, Touzi M. et al. Prevalence and factors associated to low back pain among hospital staff. Joint Bone Spine. 2005;72(3):254-9.

24. Andrusaitis, SF, Oliveira, RP, Barros Filho TE. Study of the prevalence and risk factors for low back pain in truck drivers in the state of Sao Paulo, Brazil. Clinics. 2006;61(6):503-10.

25. Falavigna A, Teles AR, Mazzocchin T, de Braga GL, Kleber FD, Barreto F, et al. Increased prevalence of low back pain among physiotherapy students compared to medical students. Eur Spine J. 2011;20(3):500-5.

26. Cavalcante Filho DE, Viana CN, Cabral MD, Cunha FV, Pacheco FD, Brito AK Dor lombar em adolescentes: um rastreamento escolar. J Human Growth Dev. 2014;24(3):347-52.

27. Noll M, Candotti CT, Rosa BN, Loss JF. Back pain prevalence and associated factors in children and adolescents: an epidemiological population study. Rev Saude Publica. 2016;50:31.

28. Silva AP, Khalil S, Marta HR, Oscar CP. Prevalence of chronic pain and associated factors among medical students. Rev Dor. 2017;18(2):108-11.

29. Almeida IC, Sa KN, Silva M, Baptista AF, Matos, MA, Lessa I. Prevalência de dor lombar crônica na populaça da cidade de Salvador. Rev Bras Ortop. 2008;43(3):96-102.

30. Fernandes RC, Carvalho FM, Assuncao AA. Prevalence of musculoskeletal disorders among plastics industry workers. Cad Saude Publica. 2011;27(1): 78-86.

31. Ferreira GD, Silva MC, Rombaldi AJ, Wrege ED, Siqueira FV, Hallal PC. Prevalencia de dor nas costas e fatores associados em adultos do Sul do Brasil: estudo de base populacional. Rev Bras Fisioter. 2011;15(1):31-6.

32. Capaldo G. Lombalgia come problema sociale. Scienza Riabilitat. 2005;7(2):5-20.

33. Siqueira FV, Facchini LA, Hallal PC. Epidemiology of physiotherapy utilization among adults and elderly. Rev Saude Publica. 2005;39(4):663-8.

34. Quiton RL, Greenspan JD. Sex differences in endogenous pain modulation by distracting and painful conditioning stimulation. Pain. 2007;132(Suppl 1):S134-49.

35. Silva MC, Fassa AG, Valle NC. Chronic low back pain in a Southern Brazilian adult population: prevalence and associated factors. Cad Saude Publica. 2004;20(2):377-85.

36. Oliveira JG, Salgueiro MM, Alfieri FM. Lombalgia e Estilo de Vida. Cient Cienc Bio Saude. 2014;16(4):341-4.

37. Dijken CB, Fjellman-Wiklund A, Hildingsson C. Low back pain, lifestyle factors and physical activity: a population-based study. J Rehabil Med. 2008;40(10):864-9.

38. Fonseca R, Serranheira F. Sintomatologia musculoesqueletica autoreferida por enfermeiros em meio hospitalar. Rev Port Saúde Pública. 2006;6(1):37-44.

39. Serranheira F, Pereira M, Santos CS. Auto-referência de sintomas de lesôes musculo-esqueleticas ligadas ao trabalho LMELT numa grande empresa em Portugal. Rev Port Saúde Pública. 2003;21(2):37-48.

40. Dominguez AG, Alves D, Gomes EP, Ewerton, FM. Prevalência de Lombalgia em acadêmicos e funcionários do Centro Universitário UNIEURO. Rev Habilitar. 2008;1(2):63-8.

41. Souza AV, Cardoso JP, Rocha SV, Amorim CR, Carneiro LRV, Vilela AB. Nível de atividade física e lombalgia entre funcionários de uma instituição de ensino superior no nordeste do Brasil. Rev Bras Promoçấo Saúde. 2011;24(3):199-206. 